\title{
Current Controversies in Stem-Cell Treatment of Urinary Incontinence
} in Women

\author{
Maria Luisa Sanchez Ferrer*, Francisco Machado-Linde, Maria Teresa Prieto-Sanchez and Anibal Nieto-Diaz \\ Obstetrics and Ginecology Department of University and Clinical Hospital Virgen de la Arrixaca, Murcia, Spain
}

\begin{abstract}
Background: Urinary incontinence (UI) is a major cause of morbidity in the world and is believed to affect up to $46 \%$ of the female population Our objective was to analyze the papers that describe stem-cell treatments for UI in women.

Methods: We performed a systematic review of the literature from 1946 to date that reports on clinical trials that use stem cells to treat women with urinary incontinence.

Results: Nine articles ( 7 observational and 2 randomized studies) met the inclusion criteria. No major adverse effects were observed in any of the studies. However, the efficacy results differ widely, as the methodology used for studies was very different, as described below.

Conclusion: Stem-cell therapy is promising but still experimental, and further study is needed to identify certain factors. These facts include the ideal type of patient eligible for treatment (apparently those in whom intrinsic urethral dysfunction predominates), and to determine if treatment should be isolated or combined with other cells or procedures, which are the optimal doses and if it is a cost effective procedure.
\end{abstract}

\section{Introduction}

Urinary incontinence (UI) is a major cause of morbidity in the world and is believed to affect up to $46 \%$ of the female population. There are several types of incontinence: urge incontinence or abnormal detrusor activity, stress incontinence (due to inherent sphincter weakness or patients with urethral hypermobility) and mixed incontinence. The most common form of urinary incontinence is stress (SUI), which is currently treated by rehabilitation treatment and surgical techniques, but the effectiveness of these methods is reported to be lower over time. Urge incontinence is often treated which anticholinergic or beta-adrenergic drugs as first line teraphy. Stem-cell therapy for the treatment of stress urinary incontinence is promising but still experimental, and further study is needed to identify certain factors. Our Objective was to analyze the papers that describe stem-cell treatments for women with urinary incontinence to investigate which is the actual Knowledge at this moment specially which are patient population was targeted (which subtype of stress urinary incontinence: only patients with SUI due to inherent sphincter weakness or patients with urethral hypermobility), where is the best site and the best procedure to inject this cells, which is the type of stem cells used and the better dose, and finally what are the results in terms of safety, effectiveness and efficiency.

\section{Material and Methods}

We performed a systematic review of the literature from 1946 to date that reports on clinical trials that use stem cells to treat women with urinary incontinence. A systematic review was performed according to PRISMA guidelines using PICO criteria.

\section{Results and Discussion}

Nine articles (7 observational and 2 randomized studies) met the inclusion criteria (Table 1). No major adverse effects were observed in any of the studies. However, the efficacy results differ widely, as the methodology used for studies was very different, as described below. All studies were phase II prospective observational studies, except for 2 randomized studies $[1,2]$, in which patients were randomized to different doses of stem cells.

\section{Types of stem cell}

In terms of the type of stem cell used, most of the studies used autologous myoblasts collected from biopsies of striated muscle (biceps, pectoral, deltoids, etc.) because muscle cells have the greatest capacity to generate muscle fibers and repair damaged urethral sphincters. Two studies [3, 4] also used autologous fibroblasts for the urethra submucosa, and the study by Lee [5] used stem cells from heterologous umbilical cord. These authors based their approach on a paper by Thornell et al [6], which confirmed that autologous muscle cell efficiency decreases with age.

\section{Inclusion criteria of patients in studies for the treatment of urinary incontinence with stem cells}

The inclusion criteria for patients are extremely varied, even within each individual study. All studies excluded urge incontinence or abnormal detrusor activity except for the study by Lee [5], which included 9 patients with mixed UI. However, in SUI, some only required that the patient had stress urinary incontinence (regardless of severity) $[2,5,7,8]$ whereas others include only patients with SUI due to inherent sphincter weakness or at least exclude patients with urethral hypermobility $>45^{\circ}[1,3,9,10]$. Nonetheless, it appears that the purpose of stem cells is to regenerate damaged sphincters, rather than to provide urethral support; in fact, some studies exclude patients with prolapse $[2,4,9]$. In most studies, this treatment was tested in patients who had experienced previous failure of conservative treatment, including electrical stimulation [2,5,7-9]. One study [3] began with rehabilitation treatment, then performed stem-cell injection,

"Corresponding Author: Maria Luisa Sanchez Ferrer, Obstetrics and Ginecology Department of University and Clinical Hospital Virgen de la Arrixaca, Murcia, Spain; E-mail: marisasanchezferrer1@gmail.com

Citation: Sanchez Ferrer ML, Machado- Linde F, Prieto-Sanchez MT, Nieto-Diaz A (2014) Current Controversies in Stem-Cell Treatment of Urinary Incontinence in Women. Int J Gynecol Clin Pract 1: 102. doi: http://dx.doi.org/10.15344/23944986/2014/102

Copyright: (C) 2014 Sanchez Ferrer et al. This is an open-access article distributed under the terms of the Creative Commons Attribution License, which permits unrestricted use, distribution, and reproduction in any medium, provided the original author and source are credited. 
Citation: Sanchez Ferrer ML, Machado- Linde F, Prieto- Sanchez MT, Nieto-Diaz A (2014) Current Controversies in Stem-Cell Treatment of Urinary Incontinence in Women. Int J Gynecol Clin Pract 1: 102. doi: http://dx.doi.org/10.15344/2394-4986/2014/102

Page 2 of 3

\begin{tabular}{|c|c|c|c|c|c|c|}
\hline $\begin{array}{l}\text { Reference } \\
\text { Year of Publication }\end{array}$ & Study Design & $\mathrm{n}$ & Number of Stem Cells & Injection Site & Outcomes & $\begin{array}{l}\text { Follow- } \\
\text { up, m }\end{array}$ \\
\hline [1] Sebe 2012 & $\begin{array}{l}\text { Randomized } \\
3 \text { doses }\end{array}$ & 12 & $\begin{array}{l}\text { Myoblasts } \\
\text { Group 1: } 1 \times 10^{7} \\
\text { Group 2: } 2.5 \times 10^{7} \\
\text { Group 3: } 5 \times 10^{7}\end{array}$ & Sphincter & $\begin{array}{l}25 \% \text {, cures } \\
83 \% \text {, improvement } \\
\text { (dose-independent) }\end{array}$ & 12 \\
\hline [2] Carr 2013 & $\begin{array}{l}\text { Randomized } \\
2 \text { doses }\end{array}$ & 38 & $\begin{array}{l}\text { Myoblasts } \\
\text { Low dose: } 1-16 \times 10^{6} \\
\text { High dose: } 32-128 \times 10^{6}\end{array}$ & $\begin{array}{l}2 \text { sphincter areas, cystoscope } \\
84 \% 2 \text { doses }\end{array}$ & $\begin{array}{l}88.9 \% \text {, improvement high dose } \\
61.5 \% \text {, improvement, low dose } \\
5.3 \% \text { worsen }\end{array}$ & 18 \\
\hline [3] Mittelberguer 2007 & $\begin{array}{l}\text { Prospective } \\
\text { interventional } \\
+ \text { electrical } \\
\text { stimulation }\end{array}$ & 123 & $\begin{array}{l}\text { Myoblasts } 2.8 \times 10^{7} \\
\text { Fibroblasts } 3.8 \times 10^{7}\end{array}$ & $\begin{array}{l}\text { Rhabdosphincter and submucosa, } \\
\text { ultrasound guided }\end{array}$ & $\begin{array}{l}79 \%, \text { dry } \\
13 \% \text {, improvement } \\
9 \% \text {, mild improvement }\end{array}$ & 12 \\
\hline $\begin{array}{l}\text { [4] Mittelberguer } 2007 \\
2008\end{array}$ & $\begin{array}{l}\text { Prospective } \\
\text { interventional } \\
+ \text { electrical } \\
\text { stimulation }\end{array}$ & 20 & $\begin{array}{l}\text { Myoblasts } 1-3 \times 10^{7} \\
\text { Fibroblasts } 1.4-6.06 \times 10^{7}\end{array}$ & $\begin{array}{l}\text { Rhabdosphincter and submucosa, } \\
\text { ultrasound-guided }\end{array}$ & $\begin{array}{l}89 \% \text {, dry } \\
11 \% \text {, improvement }\end{array}$ & 24 \\
\hline [5] Lee 2010 & $\begin{array}{l}\text { Prospective } \\
\text { interventional }\end{array}$ & 39 & $\begin{array}{l}\text { Umbilical cord } \\
4.3-1.9 \times 10^{8}\end{array}$ & $\begin{array}{l}\text { Ureterovesical juncture, } \\
\text { ultrasound-guided }\end{array}$ & $72.2 \%$, improvement & 12 \\
\hline [6] Stangel 2013 & $\begin{array}{l}\text { Prospective } \\
\text { interventional }\end{array}$ & 16 & Myoblasts $0.6-25 \times 10^{6}$ & Rhabdosphincter, cystoscope & $\begin{array}{l}50 \% \text {, dry } \\
25 \% \text {, improvements } \\
25 \% \text {, no improvement }\end{array}$ & 24 \\
\hline [7] Carr 2008 & $\begin{array}{l}\text { Prospective } \\
\text { interventional }\end{array}$ & 8 & Myoblasts $18-22 \times 10^{6}$ & $\begin{array}{l}\text { Rhabdosphincter, cystoscope } \\
\text { ( } 3 \text { patients, reinjection at } 3 \\
\text { months) }\end{array}$ & $\begin{array}{l}12.5 \% \text {, dry } \\
62.5 \% \text {, improvement }\end{array}$ & 10 \\
\hline [8] Blaganje 2012 & $\begin{array}{l}\text { Prospective } \\
\text { interventional } \\
+ \text { electrical } \\
\text { stimulation }\end{array}$ & 38 & $\begin{array}{l}\text { Myoblasts } \\
1 \times 10^{6}-5 \times 10^{7}\end{array}$ & $\begin{array}{l}\text { Rhabdosphincter, ultrasound- } \\
\text { guided ( } 26 \text { injections) }\end{array}$ & $\begin{array}{l}13.5 \% \text {, cured } \\
78.4 \% \text {, improvement } \\
8 \% \text {, equal }\end{array}$ & 1.5 \\
\hline [9] Surcel 2012 & $\begin{array}{l}\text { Prospective } \\
\text { interventional }\end{array}$ & 8 & Myoblasts & $\begin{array}{l}\text { Middle urethra, ultrasound- } \\
\text { guided }\end{array}$ & - & 12 \\
\hline
\end{tabular}

Table 1: Comparison of the main characteristics of stem cell studies in women with urinary incontinence.

and later performed electrical stimulation for 4 weeks; according to the author this favored stem-cell integration and regeneration. This was also combined with electrical stimulation in the study by Blaganje [9]. Only 1 study [2] considered prior treatment with bulking agents to be an exclusion criterion. A history of anti-incontinence surgery was an exclusion criterion in some studies [9] and an inclusion criterion for others [2]. The series reported by Lee [5] also included 1 patient with a history of surgery. The series studied by Mittelberger [3] was the largest (123 patients), 68 of whom had a history of surgery for incontinence. Naturally, most studies included patients after the physical examination, quality-of-life questionnaires (varied according to author), pad test, urinary diary, urodynamic study, etc., and different criteria were used to select the patients: eg, the pad test threshold was $>5 \mathrm{~g}$ in 1 hour for Sebe [1] and > $\mathrm{g}$ in 1 hour for Blaganje [9]. The urodynamic criteria were almost unanimous in requiring normal bladder capacity and absence of obstruction.

\section{Number of stem cell implanted}

The stem-cell culture methods also varied considerably according to the author, although even more importantly, there was considerable variation in the number of stem cells to be injected (range, $1 \times 10^{6}$ to $\left.4.3 \times 10^{6} \pm 1.9 \times 10^{8}\right)$. Some papers stressed research on the ideal number of stem cells; for instance, the randomized studies [1] and [2] compared 2 doses: [1] had 3 arms and found no correlation between the outcomes and the doses used, whereas the other [2] achieved better efficacy in patients who received doses $>32 \times 10^{6}$. Both also reported that all doses were equally safe. Another study [7] concluded that a small amount of cells $\left(1 \times 10^{6}\right)$ was sufficient to achieve continence in some patients.
One of the aspects of concern is whether the local injection of stem cells could have a bulky effect (ie, space-occupying) and, therefore, work for this reason. However, some evidence contradicts these theories. Firstly, there is no correlation showing a stronger effect at higher amounts. Secondly, some articles report that efficacy increases over time after the injection, for instance, Lee reports that $78 \%$ improve by 1 month and $80.5 \%$ by 3 months. Other studies measured postinjection sphincter electromyographic activity, finding a significant improvement (from 34 to $54 \mu \mathrm{N}$ ), and also measured urethral closure pressure during voluntary contraction (from 0.65 to 1.39 ) $[3,4]$.

\section{Site and instruments for stem cell injection}

Another point of debate is the optimal site and instrument for stemcell injection. All studies used local anesthesia, most often in the rhabdosphincter [2-4,7-9] under ultrasound or cystoscope guidance. The optimal number of injections is unclear (Blaganje: 2 levels, 26 injections; Surcel: 20 injections in middle urethra; Lee at 4 and 8 oclock in the vicinity of the urethra and submucosa area; Mittelberguer: myoblast infiltration in the rhabdosphincter and fibroblasts in the submucosa area at 3 levels; Carr 2008, 5 circumferential injections in sphincters; Carr 2013, in 2 areas of the sphincter; Polish studies: at 3 levels).

Several studies (eg, Carr) repeat the dose at 3 months. In [8], patients who had partial improvement and who had improvement at 4 to 8 months but no cure were offered reinjection. In 2013, patients were given an opportunity to receive repeat doses (doses were randomized); $84 \%$ chose the procedure and the best outcomes were observed in this 
Citation: Sanchez Ferrer ML, Machado- Linde F, Prieto- Sanchez MT, Nieto-Diaz A (2014) Current Controversies in Stem-Cell Treatment of Urinary Incontinence in Women. Int J Gynecol Clin Pract 1: 102. doi: http://dx.doi.org/10.15344/2394-4986/2014/102

Page 3 of 3

group and were independent of total dose.

\section{Results: safety, effectiveness and efficiency}

All studies reported similar safety results. The procedure is safe regardless of the total dose received and showed no noteworthy adverse reactions, even in the study that used heterologous stem cells [5]. The number of participants in each study varied between 8 [10] and $126[3]$.

In terms of effectiveness, there are important differences, as to be expected in view of the variability in inclusion criteria described above. The outcomes were measured by physical examination, quality-of-life questionnaires, pad test, urinary diary, transurethral ultrasound , and urodynamic test. Other techniques, such as electromyogram $[3,4]$, were rarely used. Mittelberguer [4] obtained the best medium-term results, specifically a cure (dry) rate of $90 \%$ at 1 year of follow-up and $89 \%$ at 2 years, with all others improving. This was the only study to inject 2 types of stem cells (myoblasts and fibroblasts) and to use the

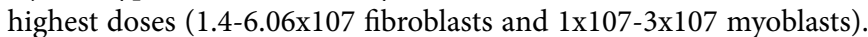
Stangel [7] also obtained good outcomes with cure obtained by $50 \%$ and partial improvement by $25 \%$ ). Sebe [1] observed $25 \%$ dry patients (83\% with improvement), Blaganje [9] 13.5\% with cure, $78.4 \%$ with improvement, and Carr [8] 12.5\% with cure and $62.5 \%$ with improvement. All others reported no cure, but did see improvement: Lee [5] reported $72.2 \%$ at 1 year, and Carr [2], $88.9 \%$ in patients at high doses and $61.5 \%$ in patients at low doses at 18 months. Surcel et al. [10] implantated stem cell in the urethral sphincter in four patients with stress urinary incontinence and compared the results of the urodynamic investigations of female patients operated with pure SUI with other surgical techniques. The analyzed procedures were: Burch colposuspension (11 cases), TVT-like (IVS sling in 26 cases), TOT-like (CYSTO-SWING sling in 41 cases). For female patients with myoblasts implant, changes in $\mathrm{Q}_{\max }$ and $\mathrm{P}_{\text {ves }}$ at $\mathrm{Q}_{\max }$ were minimal and statistically insignificant in the context of inclusion criteria but they noticed a trend of minimal change in these urodynamic characteristics, namely, an average decrease of Qmax with $2.1 \mathrm{~mL} / \mathrm{s}$ and an average increase of $\mathrm{P}_{\text {ves }}$ at $\mathrm{Q}_{\max }$ with $0.6 \mathrm{~cm} \mathrm{H}_{2} \mathrm{O}$.

\section{Conclusion}

Stem-cell therapy is promising but still experimental, and further study is needed to identify certain factors. These facts include the ideal type of patient eligible for treatment (apparently those in whom intrinsic urethral dysfunction predominates), and to determine if treatment should be isolated or combined (with electrical stimulation), if the treatment should be offered when conservative treatment has failed or when anti-incontinence surgical techniques have failed (the cost difference is significant, being estimated at $€ 1,400$ for the tension-free vaginal tape procedure, compared with $€ 5,000$ per stem-cell injection [11]). It is also unclear which type of stem cell is best for infiltration, or even whether it should be a single or combined type. Additionally, there is little information on the effective dose or on whether success is dose-dependent. Although the site is the rhabdosphincter, it is also unclear if the treatment should be performed only at this site or also in the submucosa, how many infiltrations should be given, or if they should be repeated after several months. The long-term effectiveness of stem-cell therapy remains to be demonstrated, as the longest study was only 2 years.

\section{Competing Interests}

The authors declare that they have no competing interests.

\section{Author Contributions}

Sanchez- Ferrer ML: conception and design, acquisition of data, analysis and interpretation of data. Involvement in drafting the manuscript or revising it critically for important intellectual contents and final approval of the version to be published.

Machado-Linde F: Conception and design, acquisition of data, Analysis and interpretation of data.

Prieto- Sanchez MT: Conception and design, acquisition of data, Analysis and interpretation of data.

Nieto Diaz A: Final approval of the version to be published.

\section{References}

1. Sebe P, Doucet C, Cornu JN, Ciofu C, Costa P, et al. (2011) Intrasphincteric injections of autologous muscular cells in women with refractory stress urinary incontinence: a prospective study. Int Urogynecol J 22: 183-189.

2. Carr LK, Robert M, Kultgen PL, Herschon S, Birch C, et al. (2013) Autologous muscle derived cell therapy for stress urinary incontinence: a prospective, dose ranging study. J Urol 189: 595-601.

3. Mitterberger M, Marksteiner R, Margreiter E, Pinggera GM, Colleselli $\mathrm{D}$, et al. (2007) Autologous myoblasts and fibroblasts for female stress incontinence: a 1-year follow-up in 123 patients. BJU Int 100: 1081-1085.

4. Mitterberger M, Pinggera GM, Marksteiner R, Margreiter E, Fussenegger M et al. (2008) Adult stem cell therapy of female stress urinary incontinence. Eur Urol 53: 169-175.

5. Lee CN, Jang JB, Kim JY, Koh C, Baek JY, et al. (2010) Human cord blood stem cell therapy for treatment of stress urinary incontinence. J Korean Med Sci 25: 813-816.

6. Thornell LE, Lindstrom M, Renault V, Mouly V, Butler-Browne GS (2003) Satellite cells and training in the elderly. Scand J Med Sci Sports 13:48-55.

7. Stangel-Wojcikiewicz K, Jarocha D, Piwowar M, Jach R, Uhl T, et al. (2014) Autologous muscle-derived cell for the treatment of female stress urinary incontinence: a 2-year follow-up of a polish investigation. Neurourol Urodyn 33: $324-330$

8. Carr LK, Steele D, Steele S, Wagner D, Pruchnic R, et al. (2008) 1-year follow-up of autologous muscle-derived stem cell injection pilot study to treat stress urinary incontinence. Int Urogynecol J Pelvic Floor Dysfunct 19: 881-883.

9. Blaganje M, Lukanovic A (2012) Intrasphincteric autologous myoblast injections with electrical stimulation for stress urinary incontinence. Int $\mathrm{J}$ Gynaecol Obstet 117: 164-167.

10. Surcel C, Savu C, Chibelean C, lordache A, Mirvald C, et al. (2012) Comparative analysis of different surgical procedures for female stress urinary incontinence. Is stem cell implantation the future? Rom J Morphol Embryol 53: 151-154.

11. Aref-Adib M, Lamb BW, Lee HB, Akinnawo E, Raza MM, et al. (2013) Stem cell therapy for stress urinary incontinence: a systematic review in human subjects. Arch Gynecol Obstet 288: 1213-1221. 